\title{
Groundwater resources of Uzbekistan: an environmental and
}

\section{operational overview}

Shavkat RAKHMATULLAEV ${ }^{1,2,3}$, Frédéric HUNEAU ${ }^{2,3 *}$, Jusipbek KAZBEKOV ${ }^{4}$, Hélène CELLE-JEANTON $^{5,6,7}$, Mikael MOTELICA-HEINO ${ }^{8}$, Philippe LE COUSTUMER ${ }^{2,3}$, Jamoljon JUMANOV $^{9}$

${ }^{1}$ Tashkent Institute of Irrigation and Melioration (TIIM), 39 Kary Niyazov Street, Tashkent 100000, Uzbekistan

${ }^{2}$ Université de Bordeaux, UFR des Sciences de la Terre, B18, avenue des Facultés, 33405 Talence, France

${ }^{3}$ EA 4592 Géoressources \& Environnement, Institut EGID, 1 allée Ferdinand Daguin, 33607 Pessac, France

${ }^{4}$ International Water Management Institute (IWMI), Apt.123, House 6, Murtazaeva Street Tashkent 100000 Uzbekistan

${ }^{5}$ Clermont Université, Université Blaise Pascal, Laboratoire Magmas et Volcans, BP 10448, 63038 ClermontFerrand, France

${ }^{6}$ CNRS, UMR 6524, LMV, 63038 Clermont-Ferrand, France

${ }^{7}$ IRD, R 163, LMV, 63038 Clermont-Ferrand, France

${ }^{8}$ Université d'Orléans, CNRS/INSU Institut des Sciences de la Terre d'Orléans, UMR 6113, Campus Géosciences, 1A rue de la Férollerie, 41071 Orléa ns, France

${ }^{9}$ Institute of Hydrogeology and Engineering Geology (HYDROENGEO), 64 Khodjibaev Street, Tashkent 100041, Uzbekistan

\section{Corresponding author:}

*Frédéric HUNEAU, Université de Bordeaux, UFR des Sciences de la Terre, B18, avenue des Facultés, 33405 Talence, France

Tél:+33.5.40.00.88.41; e-mail: frederic.huneau@u-bordeaux1.fr 


\begin{abstract}
:
As a result of the massive irrigation development during the Soviet Union era and intensive chemization of agriculture, the surface runoff quality has been degraded in this arid and endorheic region. Moreover hydraulically related groundwater has been affected too. Excessive irrigation has lead to land salinization which now threatens the soil quality of significant areas where crop yields would be at risk in the future. After the collapse of the Soviet Union, institutional changes have been undertaken for the management of the natural resources and the water infrastructure. At present, underdeveloped and inadequate systems have been practiced with respect to groundwater use and management. The aim of this paper is to analyze the present extent of groundwater resources with consideration to their reserves, quality evolution, and to technical, institutional and transboundary management aspects in Uzbekistan.
\end{abstract}

Key words: Aquifer; Irrigation; Hydrogeology; Water management; Salinization; Central Asia 


\section{Introduction}

Groundwater resources have been widely used for various purposes around the world mainly for domestic drinking water supply and industry. In arid countries, where erratic precipitation and limited surface runoff resources prevail, groundwater has been used also for irrigation as well (Shah 2007; Giardano 2009; Siebert et al. 2010). Groundwater resources were not widely used for irrigated agriculture in Central Asian Republics during the soviet period due to sufficient amount of surface water, reliable water supply and good maintenance of irrigation infrastructure with massive funding coming from the central government. In fact, the groundwater resources were used primarily for drinking, livestock sector and very site-specific purposes.

Groundwater overexploitation is not everywhere the case in Central Asia but the drought experienced in 1998-2001 has encouraged people to consider groundwater as an alternative to the declining surface water resources. For instance, the government of Uzbekistan has issued special decrees to overcome the consequences of the drought. The main purpose of the decrees was to drill 2,600 shallow wells and to repair old wells in rural districts for population needs (Borisov et al. 2002). Then many farmers, who could afford, started to exploit groundwater for the irrigation purposes and mainly to sustain the production during low flow periods and maintain the salinity of irrigation water compatible with agriculture.

The percentage of groundwater used in irrigation amounted to $6.4 \%$ of the total irrigated water use in Uzbekistan at the end of the $20^{\text {th }}$ century (Antonov 2000). Limits to groundwater abstraction for each aquifer per annum have been established in order to avoid significant consequences to surface flow reduction over the territory of Uzbekistan. This quantity is estimated to $6.8 \mathrm{~km}^{3} /$ year for Uzbekistan (SCS of Uzbekistan 2002; Goskompriroda of Uzbekistan 2005). However, the actual groundwater abstraction is slightly superior estimated to 
$7.5 \mathrm{~km}^{3} /$ year and thus tends to lead to serious surface flow reduction (Kazbekov et al. 2007; Rakhmatullaev et al. 2009; Rakhmatullaev et al. 2011).

The problems with groundwater and pressure on it over the territory of Uzbekistan are associated with the specialization and concentration of industrial conglomerates, the development of the irrigated agriculture and the inter-basin allocation of water resources. But the main impact on groundwater resources over the last four decades is from irrigated agriculture and its immense development. Extensive irrigation development caused the soil saturation issues and the subsequent construction of horizontal (open) and vertical (groundwater wells) drainage systems (Mirzaev 1974). So now Uzbekistan is facing a situation combining the inner re-allocation of natural water resources, its degradation in both quantitative and qualitative terms (due to drainage and salinity issues) and strong disturbances of natural groundwater formation processes.

So the aim of this paper is to fill gap in the literature and provide the scientific community with information on groundwater and its related issues in Uzbekistan. Therefore the paper has three specific objectives, which puts together all the parts of the puzzle: first to discuss the extent and characterization of groundwater resources; the second objective is to overview the main environmental issues related to groundwater such as land degradation and groundwater mineralization; and lastly to review the management framework with respect to technical, institutional and transboundary dimensions under the political and economic transformation after the collapse of the former Soviet Union.

\section{General and Hydrogeological setting of Uzbekistan}

Uzbekistan is located in the heart of Central Asia with a population over 28 million and borders with Kazakhstan in the north, Kyrgyzstan in the north-east, Tajikistan in the east, Afghanistan in 
the south and Turkmenistan in the south west (Figure 1). Due to its location in inner Asia, the climatic conditions of doubly land-locked Uzbekistan, i.e. continental and severe temperature and rainfall regimes and uneven water resource distribution, forced to practice irrigated agriculture for centuries in this part of the world (O'Hara 2000; Saiko and Zonn 2000; Rakhmatullaev et al. 2003; Micklin 2004). Cotton and wheat are the major crops in Uzbekistan followed by maize, vegetables and fruits. Agricultural production in Uzbekistan is predominantly based on irrigation, which makes irrigation water supply and management the major factors limiting crop yields in the region (Ximing et al. 2003; Ibragimov et al. 2007).

The total cultivated land in Uzbekistan is estimated to be 5.2 million of ha, of which 4.2 million ha are irrigated. The irrigated lands almost increased by 3 fold over the last century; about 1.3 million ha in 1900, 2.6 million ha in 1950 and 4.2 million in 2000 with massive water and land development schemes carried out by Soviet administration in order to satisfy its cotton needs (UNEP 2005). Moreover, Uzbekistan has witnessed a population boom; in fact there was an increase of 4 fold of its population growth i.e., from 6.5 million in 1940 to over 26 million in 2007. As a result, the irrigated lands per capita has reduced from $0.41 \mathrm{ha} /$ person in 1940 to only $0.16 \mathrm{ha} /$ person in 2008 (UNEP 2005).

In Uzbekistan, which accounts for over a half of the irrigated land in the Central Asian region, it is estimated that $70 \%$ of water is lost between the river and the crop, yet poor drainage systems further exacerbates water management problems (Nezlin et al. 2004; World Bank 2005).

The north-western plain of Central Asia is characterized by very hot summer (mean July temperature about $25.5{ }^{\circ} \mathrm{C}$ ) and cold winters (mean January temperature about $2.4{ }^{\circ} \mathrm{C}$ ). Uzbekistan is open to the dry air masses formed in Arctic and Siberia coming from the North. As they are blown towards Western and Southern parts of the basin these cold air masses are heated 
and then can encounter tropical air masses coming from the South. Unstable winters over the region are resulting from this mixing front between dry cold air masses and tropical warm air masses (Aizen et al. 2001).The basin is characterized by uneven distribution and quantity of precipitation. The average mean annual precipitation over the basin is about $170 \mathrm{~mm}$ (Shultz 1949), with great contrast between north-western steppes (100 mm/year) and mountainous areas of the South-eastern (1000 mm/year). The important role of mountains and glaciers should be pointed out as these areas can store precipitation as snow and ice and deliver it through summer melting to rivers and associated alluvial aquifers during dry season (July and August). In average $95 \%$ of the basin area receives approximately less than $300 \mathrm{~mm} /$ year (Irrigation of Uzbekistan 1975) and most of the rainfall occurs in winter and spring from December to April. The dominant process in this very arid region is evapotranspiration which can potentially amount to $1500-2000$ mm/year (Letolle and Mainguet 1993, Nezlin et al. 2004) and is responsible for the loss of great volumes of water. Lioubimtseva et al. (2005) reports that a general warming trend in Central Asia on the order of 1-2 ${ }^{\circ} \mathrm{C}$ since the beginning of the $20^{\text {th }}$ century has been observed that might have a strong potential impact on the regional temperature and precipitation regime but also on natural ecosystems and agricultural crops. In fact the evaporation increase is forecasted to be around 10$15 \%$ due to global warming effects in Uzbekistan (Hagg et al. 2007).

The presence of high mountain (5000-6000m of Central Pamir and Tien Shen) systems in the south-west and western parts facilitates the formation of great water courses in the very arid conditions of the country since it can accumulate atmospheric moisture, and behave as a huge feeding reservoir (Mirzaev 1974; Borisov 1990; Aizen et al. 2001). However the major part of the territory of Uzbekistan (about 80\%) is composed of desert-steppe areas in the eastern part. The juxtaposition of mountains and deserts exerts a great influence upon the hydrogeological 
conditions, thus favoring the formation of considerable groundwater resources in a number of arid regions (Rakhmatullaev et al. 2009). The proximity of mountains and deserts in Central Asia determines the existence of two subtypes of groundwater formation in arid conditions, autochthonous and allochthonous (Ostrovsky 2007).

The autochthonous subtype is developed in regions not influenced by mountainous systems and is characterized by groundwater formation from in situ water resources, mainly from precipitation. The allochthonous subtype is typical of deserts where groundwater is formed under the influence of mountainous systems. It is commonly held that arid zones are characterized by the presence of basins that have no runoff to the ocean and where all precipitation is used up through evapotranspiration. Borisov (1990) assesses that about 5 to $22.5 \%$ of atmospheric precipitation is engaged in the formation of groundwater in Uzbekistan.

The plain regions of Uzbekistan are characterized by very complicated hydrogeological conditions and covered by alluvial sand, loam and clay dating from the Quaternary and Pliocene that can be interstratified, giving birth in some places to confined or semi-confined aquifers (Rakhmatullaev et al. 2009). Confined aquifers can also be found in the deep Cretaceous sandstone formations of the Aral Sea area and provide artesian waters. In some parts these deep groundwater can show high salinity which prevent them from any use.

A lot of shallow aquifer are salinized (1-10 g/l) or involved into salinization processes. Salinization results from agricultural practices but is also related to the sodic nature of soil like solonetz and solontchaks. It must be noted that groundwater mineralization tends to decrease with depth (Ostrovsky 2007) and that mineralization processes are strongly correlated to groundwater level rise caused by irrigation.

\section{Groundwater resources extent}


Mavlonov et al. (2003) reports that groundwater resources in Uzbekistan are estimated to be around $27 \mathrm{~km}^{3} /$ year, whereas the research Institute of Hydrogeology and Engineering Geology (HYDROENGEO) of Uzbekistan estimates this value to be around $23 \mathrm{~km}^{3} /$ year. The main recharge sources are of natural origin such as subsurface inflow, infiltration from river channels and atmospheric precipitation. $10 \mathrm{~km}^{3} /$ year or $37 \%$ of the total groundwater resources originate from subsurface inflow and precipitation whereas $63 \%$ from artificial sources (infiltration from irrigation canals and water reservoirs, and seepage from irrigated lands) (Ikramov 2006).

To assess the hydrogeological, geological and hydrological conditions, the following 13 major hydrogeological zones (Figure 2) have been established in Uzbekistan in order to estimate regional (explored) groundwater reserves (Mirzaev 1974; Irrigation of Uzbekistan 1975; Borisov 1990).

Natural and artificial groundwater recharge and discharge sources have different spatial and temporal cyclic characteristics (Akhmedov and Mavlonov 2003). The past research has shown that there are five types of water exchange for different hydrogeological structures in Uzbekistan Table 1. The duration of the groundwater resources turn-over within hydrogeologic structures and deposits is characterized by the sensitivity of these resources to impact indicators such as the natural and anthropogenic recharge and discharge factors. For example, the most rapid reaction is observed for hydrogeological massifs of fresh unconfined groundwater resources in the deltas of major rivers. These resources constitute about $12 \%$ of the total groundwater resources in Uzbekistan, whereas the duration of water turn-over for artesian aquifers (13\% of the total groundwater resources) have a prolonged impact reaction varying from 95 up to 1500 years (Akhmedov and Mavlonov 2003). Average groundwater turn-over duration of 18-50 years is typical for intermountain depressions, river valleys, piedmont loops and river debris cones; these 
resources constitute $75 \%$ of the total groundwater resources of Uzbekistan (Akhmedov and Mavlonov 2003).

The total forecasted regional groundwater reserves are of about $19.6 \mathrm{~km}^{3}$, including $7.3 \mathrm{~km}^{3}$ of waters with a salinity of up to $1 \mathrm{~g} / \mathrm{l}$ and about $10 \mathrm{~km}^{3}$ with a salinity from 1 to $3 \mathrm{~g} / \mathrm{l}$ (Figure 3 and Table 2) (Borisov et al. 2002; Chub 2004). In fact about $85 \%$ of the groundwater resource is recharged from surface water and irrigation canals; only a third is formed on the territory of neighboring countries and termed as 'transboundary' groundwater resources (UNECE 2009; Karimov et al. 2010).

\section{Groundwater use}

Although groundwater resources constitute roughly $10 \%$ of the total water resources in Uzbekistan about $60 \%$ of it is used for drinking water supply, domestic use and irrigation. In Uzbekistan, around 94 major aquifers are found mainly in the Ferghana valley (35\% out of the total), Tashkent province (26\%), Samarkand (18\%) and the remaining $21 \%$ can be found elsewhere on the territory (Table 3) (Goskompriroda of Uzbekistan 2005).

The over-use of groundwater is observed mainly in arid southern provinces of Uzbekistan ranging almost 2 times exceeding the approved groundwater resources limits. This aspect is explained by the limited surface waters and its increasing levels of pollution from irrigated agriculture thus groundwater resources have became alternative source for local livelihoods and economic development.

Figure 4 depicts the total groundwater withdrawal and use for irrigation. The observed decrease in extraction is due to the reduction of operation hours of wells, worn out of pumping systems and bad condition of wells. In addition, there is an increase in groundwater use by industry which implies competition with other sectors in a foreseen future. Individual farmers do not have 
sufficient financial and technological capacities to implement and use boreholes for lifting groundwater for crop production.

For Uzbekistan the major share of groundwater extraction is coming from borehole and dug wells thanks to heavy equipments developed during the Soviet period and still operating in many places. For example in 1992 there were about 45000 boreholes in total of which 27000 were operational (Akhmedov and Mavlonov 2003).

\section{Reforms in water management}

After the collapse of Soviet Union, the conversion from a planed centralized economy system into a market oriented one has changed dramatically the situation in water resources management in terms of institutional, political and technical systems.

Along with de-centralization in agriculture, water management system was also transformed in Uzbekistan at two levels i) river basin and ii) on-farm level (Rakhmatullaev et al. 2010). The irrigation water management was transformed from once a territorial-based management to a hydrographic principle at the river basin level. The second level is on-farm level where social complexities are observed.

The intention of the national government was to shift the operation, maintenance and management of irrigation and drainage infrastructures to non governmental institutions such as water users' associations (WUA) in the replacement of the former collective farming systems (decentralization) (Abdullaev et al. 2008). A WUA is a self-managing group of farmers working together to operate and maintain their irrigation and drainage network (only inter-farm or on-farm level) to ensure fair and equitable water distribution and increase crop yields.

The shift (decentralization) was only giving drainage facilities without proper know-how transfer programs and still many farmers believe that the central government should take care of drain 
systems for cleaning and rehabilitation. For example, the majorities of farmers do not understand the importance of drains and willingly or unintentionally destroy or dismantle such structures across the countries.

\section{Constraints for groundwater use}

\section{Financial burdens}

It is known that the use of groundwater is not economically profitable for irrigation due to its high extraction costs for installation of equipment (pumps) and ever increasing prices of electricity in Uzbekistan (Rakhmatullaev et al. 2009). Input per $1 \mathrm{~m}^{3}$ of surface gravity irrigation for a farmer is estimated to be $0.13-0.15$ US $\$$, and in the areas of pumped irrigation is about 0.3 US\$ (Karimov et al. 2010). Thus, production cost in the case of groundwater exploitation is clearly higher than that of surface water exploitation.

However, the use of groundwater resources for irrigation purposes will be justified in water scarce conditions and in special places of the territory of Uzbekistan. For instance the Government of Uzbekistan has launched a massive program in the lower reaches of Amu Darya river basin in 2001 and by 2003 there were drilled approximately 27000 boreholes, to counterpoise the pernicious effects of the drought, with depth varying between $50-500 \mathrm{~m}$ with a cost of drilling for one borehole ranging within 500-2000 US\$ (Kuchuhidze et al. 2003).

\section{Low incentives for water savings}

A state ordered agricultural production quota system (for cotton and wheat) guarantees farmers to access to banks credits (up to $60 \%$ of input costs) and a free access to surface water (gravity open irrigation canals or subsided lift irrigation water) with nominal memberships payments to WUA. 
All of which do not leave room for incentives to use groundwater. On the other hand in order to use groundwater, a farmer should bear additional costs such as payment for receiving permission from state authorities to dig borehole and its implementation costs.

\section{Absence of consultancy/extension service}

The simple public awareness campaigns or training can substantially improve the drainage situation and can still serve its design purposes.

At the moment, the management and operation of drainage systems is carried out by the state hydrogeological melioration expedition (HGME) which is under the umbrella of national Agriculture and Water Resources Ministry. The main responsibilities of this organization are to:

i) Estimate shallow groundwater table level and its mineralization levels;

ii) Quantify total drainage water runoff;

iii) Assess irrigation and drainage water quality;

iv) Determine the extent of salt-affected irrigated lands and marginal ones;

v) Drill boreholes for monitoring groundwater table level over irrigated lands.

In order to maintain existing drainage facilities and overcome the misunderstanding of local farmers not to destroy them, the HGME organization should act as consulting body (extension service) through public private partnerships. This will enable to reinforce monitoring framework and betterment of ownership from local farmers.

\section{Environmental issues related to groundwater}

The dramatic change in the quality of groundwater resources observed in some place of Uzbekistan is linked to irrigation and melioration of lands, reallocation and extraction of river 
flow especially since 1965 (over 1 million hectares of lands were transformed into irrigation) (Talipov 1992). Discharge of collector-drainage water into the river systems, its re-use and chemization of agriculture has led to regional pollution of unconfined groundwater resources by salts, nitrates and pesticides (Green 2001; Papa et al. 2004; Gadalia et al. 2005; Tookey 2007; Törnqvist 2011). Such water consumption patterns are well reflected in temporal changes in groundwater depth and salinity, which both showed a rapid increase in the late 1990s (Crosa et al. 2006).

The most critical situation is when the groundwater table is less than 2 meters from the soil surface because the salt movement is observed by capillary mechanism to the root zone and thus has direct impact on crop yield and overall soil salinity.

Figure 5 depicts the change of irrigated lands area with less than 2 meters of groundwater table in the provinces of Uzbekistan from 1992 to 1998. The surface of irrigated areas with a high groundwater table level has increased by $2 \%$ in Uzbekistan that is to say from 0.90 million ha in 1992 to 0.92 million ha in 1998 (Dukhovny et al. 2005).

The irrigated lands area with a groundwater table less than 2 meters deep have increased mostly in the upstream provinces of Uzbekistan whereas the decrease of such areas is observed in downstream ones as the downstream provinces tend to practice more groundwater withdrawal for satisfying their agricultural needs because surface runoff availability both in quantity and quality opposed to upstream areas, although the groundwater extraction regulation is uniform across Uzbekistan.

As a result of infiltration of water losses, the level of groundwater of unconfined aquifer began to rise also entailing the dissolution of salts contained in the upper part of the soil profiles (Jarsjö and Destouni 2004; Kitamura et al. 2006). This is particularly true in the lower reaches of Amu 
Darya River where groundwater resources were at 15-20m depth in 1980s, started to rise and in early 2000 were at $1-1.5 \mathrm{~m}$ depth (Borisov et al. 2002).

The overall spatial distribution of groundwater salinity shows also strong spatial association with type of aquifer rock and with the distance from the river along the main irrigation canals (Figures 2 and 3). Coarser sediments showed higher groundwater salinity than finer sediments. Pollution of groundwater occurs progressively from upstream to downstream along river stream.

Man-caused influence has lead to pollution and to decrease of groundwater resources and operational reserves of fresh groundwater resources in average (Chembarisov and Bakhritdinov 1989; Crosa et al. 2006; Törnqvist 2011).

Despite of this, farmers are forced to continue to use groundwater for agriculture, domestic, livestock and drinking purposes since no other water resources can be exploited. In the lower Amu Darya river basin of Uzbekistan, groundwater quality is also deteoriated in rural area due to very poor sewage systems (Johansson et al. 2009). Traditionally all rural households have their toilets in close vicinity (10-30m away) from their houses and as a consequence shallow groundwater is very often contaminated by sewage (Nagevich and Chebotareva 2010).

According to the national environmental protection agency, about 35-38\% of fresh explored groundwater reserves is polluted to various degrees and can not be used (Figure 6).

Figure 6 shows a general tendency of increase in groundwater resources salinity from 1992 to 1998. The most persistent situation with groundwater salinity is observed in Kashkadarya and Surkhandarya provinces where the new irrigated lands were transformed without proper drainage facilities and soils naturally of sodic type.

Moreover, the groundwater table rise has even started to threaten the famous world historical remnants (the historical buildings are mainly made of mud bricks) of heritage sites such as Samarkand, Bukhara and Khorezm. Thus the national government authorities established a 
network of monitoring wells. In Bukhara, 173 monitoring wells and 181 vertical drainage wells have been constructed for lifting and draining about $0.021 \mathrm{~km}^{3}$ of groundwater that resulted in maintaining the water table around 2.15 meters below the surface (Niyazov 2000).

\section{Melioration regime}

The melioration regime in Soviet science is interpreted as a set of interrelated conditions such as artificial and natural drainage, water supply and agro-technical operations that dictate interrelationship between irrigation water and groundwater over an irrigated field (Reshetkina 1965; Dukhovny et al. 2005). The main criteria are the supply and the zone of aeration within the concerned irrigated field. When choosing melioration regimes the natural conditions of the territory should be considered under irrigation.

In order to have clear picture first lets introduce groundwater melioration classification system used in the Soviet science. There are four types of melioration regimes namely i) hydromorphic, ii) semi-hydromorphic, iii) semi-automorphic and iv) automorphic which are characterized by the groundwater regime, their engagement in the soil formation, water supply to agricultural crops, and lastly salt and nutrient content in soil aeration zone (Table 4). These melioration regime types depend on the groundwater engagement in the total water consumption by agricultural crops. Groundwater engagement depends on water-physical soil aeration zone characteristics (texture, depth, rate of capillary force, water holding capacity and etc.). In addition, abovementioned reclamation regimes depend on the type of crop growth with supplied water quantity and draining capacities plus applied irrigation techniques (Ikramov 2006).

All of these melioration regimes can be successfully established over irrigated lands with careful investigation of relationships among environmental factors (water, air, salt and nutrient availability in aeration soil rooting zone), management factors (water supply rates, drainage 
infrastructure, agro-technical options) and consideration of cultivated crop growth. The paramount aspect in successfully establishing such regimes is sustaining natural water-salt regimes of rooting zone and inflow of water and salts from other artificial sources such as irrigation and drainage waters with proper organizational and technical works undertaken within an irrigated field plot.

The main goal of the drainage system is to decrease and maintain groundwater table under irrigated lands, flood protection, disposal of surplus precipitation and sewage disposal purposes (Freisem and Scheumann 2001).

\section{Transboundary groundwater}

Transboundary groundwaters include: aquifers which are located in two or more countries and aquifers which are used in combination with surface water, and for which changes in extracted volumes may lead to changes in surface water quantity and use (UNESCO 2001). The management of internationally shared groundwaters is of special importance in Central Asia (Struckmeier et al. 2006). The main international aquifers areas include the area around the Tuyamuyn reservoir and its supply canals between Turkmenistan and Uzbekistan; the piedmont zone in the Hungry Steppe with shared aquifers between Kazakhstan and Uzbekistan; in the Zarafshan River Basin between Tajikistan and Uzbekistan; in Fergana Valley between Kyrgyzstan and Uzbekistan (UNECE 2009; Gracheva et al. 2009; Rakhmatullaev et al. 2009).

Table 5 depicts the major international groundwater shared between Uzbekistan and its neighboring states in Central Asia. It is expected that groundwater resources would be more limited due to the climate change and everlasting competition of Central Asian states for their economic growth which rely mostly on irrigated agriculture. A key problem is the lack of legal framework and international agreements on joint groundwater management and monitoring 
systems and re-enforcement of sustainable management systems both for water abstraction and monitoring (Karimov et al. 2010). Otherwise groundwater resources would be vulnerable from depletion and pollution with heighten tensions between countries in Central Asia.

\section{Institutional groundwater management}

In the framework of the groundwater resources management and regulation several government agencies are involved in Uzbekistan (Figure 7). The main national agency is the State Committee of the Republic of Uzbekistan on Geology and Mineral Resources (Goskomgeologiya of Uzbekistan) that is primarily responsible for groundwater management in terms of investigating groundwater reserves, issuing groundwater withdrawal permits and strategic coordinating its management and use in Uzbekistan. The State Committee for Nature Protection of the Republic of Uzbekistan (Goskompriroda of Uzbekistan) monitors the groundwater quality and sanctions pollution fines of groundwater and surface runoff. In addition, the State Committee of the Republic of Uzbekistan on Safety in Industry and Mining deals with mineral and thermal groundwater resources. Yet, the Ministry of Agriculture and Water Resources of Uzbekistan through its HGME for monitoring of groundwater levels and salinity over irrigated lands.

Assessment of the legislation framework reveals that there is an overlapping and duplication of responsibilities among different state authorities within Uzbekistan for groundwater management and thus there is no clear management and policy regulation. The principal research on groundwater and hydrogeology is carried out by research institute HYDROENGEO which mainly collects data on groundwater. 


\section{Conclusion}

Groundwater resources are widely used for water supply systems and to less extent for industry and irrigation in Uzbekistan. However, as the result of the massive conversions of lands for agriculture their quality and quantity has been changes in particular fresh groundwater resources with mineralization of less than $1 \mathrm{~g} / \mathrm{l}$ has decreased by 40 percent in Uzbekistan and on the other hand higher mineralized groundwater resources are on the rise. This reduction will impact availability of high quality groundwater resources for irrigated agriculture and as drinking source for domestic water supply and livestock sectors. Groundwater resources should be carefully monitored by government agencies for their sustainable use in order to meet food security and human health. The assessment of the legislation framework has revealed the existence of some gaps concerning groundwater and we propose that groundwater specific legislation must be developed for outlining the great role of these resources.

\section{Acknowledgement}

The authors would like to thank the French Embassy in Tashkent for supporting the FrenchUzbek cooperation in the field of water sciences. This study has also been supported by INTAS fellowship Nr. 04-83-3665 and by the French Foreign Ministry of Foreign Affairs via the Eiffel fellowship program No. 530909C. 


\section{REFERENCES}

Aizen EM, Aizen VB, Melack JM, Nakamura T, Ohta T (2001) Precipitation and atmospheric circulation patterns at mid-latitudes of Asia. Int. J. Climatol 21:535-556

Abdullaev I, Nurmetova F, Abdullaeva F, and Lamers J (2008) Socio-technical aspects of Water Management in Uzbekistan: emerging water governance issues at the grass root level. In M. M. Rahaman, O. Varis (Eds.), Central Asian Waters: Social, economic, environmental and governance puzzle. 89-103. Helsinki, Finland: Helsinki University of Technology.

Akhmedov NA, Mavlonov AA (2003) Groundwater resources of Uzbekistan and their directions of rational use. Proceedings of International conference on Development of Systems for Rational Use of Surface and Groundwater in Aral Sea Basin, pp 93-100. Tashkent, Uzbekistan

Antonov VI (2000) Water resources of Uzbekistan as part of total water resources of Aral Sea Basin and their use under current conditions and in future. In: Water resources, issues, Aral Sea and environment. Publisher "Universitet", Tashkent, Uzbekistan, pp 19-39

Borisov VA, Vavlenko LI, Musaev TP, Sultanova DG (2002) Index assessment of quality of drinking groundwater of Uzbekistan. A paper presented at the conference on drinking water supply and ecology, Tashkent, Uzbekistan

Borisov VA (1990) Groundwater resources and their use in national economy. Publisher "Fan", Tashkent, Uzbekistan

Chembarisov EI, Bakhritdinov BA (1989) Hydrochemistry of river and drainage water resources of Central Asia. Publisher "Ukituvchi”, Tashkent, Uzbekistan

Crosta G, Stefani F, Bianchi C, Fumagalli A (2006) Water security in Uzbekistan: implication of return waters on the Amu Darya Water Quality. Environ Sci \& Pollut Res 13:37-42 
Chub VE (2004) Water quality of surface runoff resources in Aral Sea basin. Proceedings of International Symposium on Fresh water pollution in arid zone: Assessment and Reduction. pp. 78-79. Tashkent, Uzbekistan

Dukhovny VA, Yakubov KhI, Umarov PD (2005) Relationship between irrigation and drainage. In: Pereira LS, Dukhovny VA, and Horst MG (eds) Management of irrigation for combating desertification in Aral Sea Basin: Assessment and instruments. Publisher "Vita Color", Tashkent, pp 299-315

Freisem C, Scheumann W (2001) Institutional arrangements for land drainage in developing countries. Working Paper 28. Colombo, Sri Lanka: International Water Management Institute.

Gadalia A, Motelica-Heino M, Serra H, Abou Akar A, Jouin F, Charpy A (2005) Inorganic pollutants of the Syr-Daria River (Kazakh Priaralie). Tethys Geographical Research I:79-92

Giordano M (2009) Global groundwater? Issues and solutions. Annu. Rev. Environ. Resour. 34:7.1-7.26. doi: 10.1146/annurev.environ.030308.100251

Gracheva I, Karimov A, Turral H, Miryusupov F (2009) An assessment of the potential and impacts of winter water banking in the Sokh aquifer, Central Asia. Hydrogeology Journal 17:1471-1482. doi10.1007/s10040-009-0444-0

Green DJ (2001) Regional co-operation policies in Central Asia. Journal of International Development 13:1151-1164

Hagg W, Braun LN, Kuhn M, Nesgaard TI (2007) Modelling of hydrological response to climate change in glacierized Central Asian catchments. Journal of Hydrology 332:40-53 
Ibragimov N, Evett SR, Esanbekov Y, Kamilov BS, Mirzaev L, Lamers JPA (2007) Water use efficiency of irrigated cotton in Uzbekistan under drip and furrow irrigation. Agricultural Water Management 90:112-120

Ikramov R (2006) Groundwater management at irrigated lands of Uzbekistan and its influence on ecological system. In: Baba A et al (ed) Groundwater and ecosystems. Springer, Netherlands, pp 145-152

Irrigation of Uzbekistan: Irrigation development in a complex of production forces of Uzbekistan (1975) Vol. I. Publisher "Fan”, Tashkent, Uzbekistan

Jarsjö J, Destouni G (2004) Groundwater discharge into the Aral Sea after 1960. J Mar Syst 47:109-120

Johansson O, Aimbetov I, Jarsjö J (2009) Variation of groundwater salinity in the partially irrigated Amudarya River delta, Uzbekistan Journal of Marine Systems, 76(3): 287-295

Karimov A., Smakhtin V., Borisov V., Jumanov J (2010) Transboundary aquifers of the Fergana Valley: Challenges and opportunities. A paper presented at International UNESCO Conference on "Transboundary aquifers: Challenges and new directions", pp.72-73. Paris, France, 6-8 December 2010.

Kazbekov J, Rakhmatullaev S, Huneau F, Le Coustumer Ph (2007) Types and hydrogeologic features of surface and groundwater interactions in Uzbekistan. Paper presented at the $35^{\text {th }}$ International Association of Hydrogeologists Congress on Groundwater and Ecosystems, Lisbon, Portugal, 17-21 September 2007. CD of the Conference Proceedings, ISBN978-989-95297-3-1

Kitamura Y, Yano T, Honna T, Yamamoto S, Inosako K (2006) Causes of farmland salinization and remedial measures in the Aral Sea basin, Research on water management to prevent 
secondary salinization in rice-based cropping system in arid land. Agricultural Water Management 85:1-14

Kuchuhidze TV, Mavlonov AA, Krasnikov VV (2003) Lessons of drought in 2001 in Karakalpakistan. A paper presented at the conference on development of systems on rational use of surface and groundwater resources in Aral Sea Basin. Tashkent, Uzbekistan, 5-6 July 2003

Létolle R, Mainguet M (1993) Aral. Springer, Paris, p 357

Lioubimtseva E, Cole R, Adams JM, Kapustin G (2005) Impacts of climate and land-cover changes in arid lands of Central Asia. Journal of Arid Environments 62:285-308. Doi:10.1016/j.jaridenv.2004.11.005

Mavlonov AA, Borisov VA, Khamitov G (2003) Evolution of groundwater resources in the Republic of Uzbekistan. In Proceedings of International conference on Development of Systems for Rational Use of Surface and Groundwater in Aral Sea basin, pp 93-100. Tashkent, Uzbekistan

Micklin Ph (2004) The Aral Sea crisis. In: Nihoul J, Zavialov P, Micklin Ph (Eds), Dying and dead seas-Climatic versus anthropic causes, pp. 49-76. Kluwer Academic Publishers, Netherlands

Mirzaev SS (1974) Groundwater reserves of Uzbekistan. Publisher "Fan", Tashkent, Uzbekistan Nezlin NP, Kostianoy AG, Lebedev SA (2004) Interannual variations of the discharge of Amu Darya and Syr Darya estimated from global atmospheric precipitation. Journal of Marine Systems 47:67-75

Nagevich PP, Chebotareva OV (2010) Uzbekistan karizes and use of ancestors experience on building groundwater gallery. In Zuber A, Kania J, Kmiecik E (eds) Groundwater Quality Sustainability. University of Silesia Press 2010, Poland, pp 821-827 
Niyazov R (2000) Changing of groundwater level and contemporary deformations of ancient architectural monuments of Samarkand, Bukhara and Khiva. In Proceedings of Regional workshop on Groundwater and soil salinity related damage to the monuments and sites in Central Asia. pp. 48-51. UNESCO, Samarkand/Bukhara, Uzbekistan

O'Hara SL (2000) Lessons from the past: water management in Central Asia. Water Policy 2: 365-384. PII: 1366-7017(00)00010-6

Ostrovsky VN (2007) Comparative analysis of groundwater formation in arid and super-arid deserts (with examples from Central Asia and Northeastern Arabian Peninsula). Hydrogeology Journal 15:759-771

Papa E, Castiglioni S, Gramatica P, Nikolayenko V, Kayumov O, Calamari D (2004) Screening the leaching tendency of pesticides applied in the Amu Darya Basin (Uzbekistan). Water Research 38:3485-3494

Rakhmatullaev S, Huneau F, Kazbekov J, Le Coustumer P, Jumanov J, El Oifi B, MotelicaHeino M, Hrkal Z (2009) Groundwater resources and management in the Amu Darya River Basin (Central Asia). Environ Earth Sci. 59:1183-1193. doi:10.1007/s12665-009$0107-4$

Rakhmatullaev S, Huneau F, Le Coustumer P, Motelica-Heino M (2010) Sustainable irrigated agricultural production of countries in economic transition: Challenges and Opportunities (A case study of Uzbekistan, Central Asia). In Agricultural Production, edited by Felix C. Wager, Nova Science Publishers, New York, 139-161. ISBN:978-161668-695-6

Rakhmatullaev S, Marache A, Huneau F, Le Coustumer P, Bakiev M, Motelica-Heino M (2011) Geostatistical approach for the assessment of the water reservoir capacity in arid 
regions: A case study of the Akdarya reservoir, Uzbekistan. Environmental Earth Sciences, 63, 447-460. DOI: 10.1007/s12665-010-0711-3

Rakhmatullaev S, Bazarov DR, Kazbekov JS (2003) Historical irrigation development in Uzbekistan from ancient to present: Past lessons and future perspectives for sustainable development. In Proceedings of the third International Conference of International Water History Association, pp 79-80. Alexandria, Egypt

Reshetkina NM (1965) Hydrogeological bases of vertical drainage. Publisher "Fan" Tashkent, Uzbekistan

Saiko TA, Zonn IS (2000) Irrigation expansion and dynamics of desertification in the CircumAral region of Central Asia. Journal of Applied Geography 20:349-367. PII: S01 43 6228(00)00014-X

Siebert S, Burke J, Faures JM, Frenken K, Hoogeveen J, Doll P, Portmann FT (2010) Groundwater use for irrigation - a global inventory. Hydrol. Earth Syst. Sci., 14, 18631880. doi:10.5194/hess-14-1863-2010

State Committee of the Republic of Uzbekistan on Statistics (SCS of Uzbekistan) (2002) Environmental protection in Uzbekistan: Statistical bulletin. Tashkent, Uzbekistan Shah T (2007) Groundwater: A global assessment of scale and significance. IWMI Report. International Water Management Institute, Sri Lanka Shultz V (1949) Central Asian rivers. Publisher "Nauka” Moscow, Russia Goskompriroda of Uzbekistan [State Committee for Nature Protection of the Republic of Uzbekistan] (2005) Conditions of environment and use of natural resources in Uzbekistan (2002-2004), National report. Tashkent, Uzbekistan 
Struckmeier WF, Gilbrich WH, Gun JVD, Mauer T, Puri S, Richts A, Winter P, Zaepke M (2006) WHYMAP and the world map of transboundary aquifer systems at the scale of 1:50,000,000. UNESCO, 4th world water forum, Mexico City, March 2006

Talipov GA (1992) Land resources of Uzbekistan and their rational use. Publisher “Uzinfopmagroprom”, Tashkent, Uzbekistan

Tookey DL (2007) The environment, security and regional cooperation in Central Asia. Journal of Communist and Post-Communist Studies 40:191-208. Doi:10.1016/j.postcomstud.2007.03.004

Törnqvist R, Jarsjö J, Karimov B (2011) Health risks from large-scale water pollution: Trends in Central Asia. Environment International 37: 435-442. doi:10.1016/j.envint.2010.11.006 UNEP (2005) Global International Waters Assessment Aral Sea, GIWA Regional assessment 24. University of Kalmar, Kalmar, Sweden

UNESCO (2001) Internationally shared (Transboundary) aquifer resources management, their significance and sustainable management. IHP-VI, IHP non-Serial publications in hydrology SC-2001/WS/40, November 2001, UNESCO, Paris, p 71

UNECE (2009) Facts and figures on transboundary groundwaters in Caucasus and Central Asia. Chapter 6. In: Our waters: Joining hands across borders. First assessment of $\begin{array}{lll}\text { transboundary } & \text { rivers, } & \text { lakes }\end{array}$ groundwaters.http://unece.org/env/water/publications/assessment/gw_cacena_6.pdf Accessed 7 April 2009

World Bank (2005) Drought: Management and mitigation assessment (for Central Asia and the Caucasus). Report No. 31998-ECA

Ximing C, McKinney DC, Rosegrant MW (2003) Sustainability analysis for irrigation water management in the Aral Sea region. Agricultural Systems 76:1043-1066 


\section{CAPTIONS OF FIGURES}

Figure 1 Location of Uzbekistan

Figure 2 Hydrogeological map of Uzbekistan (adapted and modified from Goskompriroda of Uzbekistan 2005)

Figure 3 Salinity, schematic distribution and withdrawal of groundwater resources in Uzbekistan (adapted and modified from Goskompriroda of Uzbekistan 2005)

Figure 4 Total groundwater extraction and for irrigation, 1976-2004 (Borisov 1990; Mavlonov et al. 2003; Goskompriroda of Uzbekistan 2005)

Figure 5 Change of irrigated lands area with a groundwater table less than 2 meters deep in Uzbekistan, 1992-1998

Figure 6 Weighted average of groundwater salinity between 1992 and 1998 across administrative provinces of Uzbekistan

Figure 7 Institutional framework in groundwater management in Uzbekistan 


\section{TABLE LIST}

Table 1. Main types of water cycle for different hydrogeological conditions in Uzbekistan (Mirzaev 1974; Mavlonov et al. 2003)

Table 2. Forecasted groundwater reserves with a mineralization of less than $5 \mathrm{~g} / \mathrm{l}$ in Uzbekistan (Mirzaev 1974; Borisov 1990)

Table 3. Number of aquifers in administrative provinces of Uzbekistan as of 2004 (Goskompriroda of Uzbekistan 2005)

Table 4. Melioration regime characteristics (Reshetkina 1965; Dukhovny et al. 2005; Ikramov 2006)

Table 5. Major transboundary aquifers and environmental and management issues in Uzbekistan (UNECE 2009) 
Table 1. Main types of water cycle for different hydrogeological conditions in Uzbekistan (Mirzaev 1974; Mavlonov et al. 2003)

\begin{tabular}{llcc}
\hline Type & \multicolumn{1}{c}{ Hydrogeological conditions } & \multicolumn{2}{c}{$\begin{array}{c}\text { Duration of water cycle } \\
\text { (years) }\end{array}$} \\
\cline { 3 - 4 } & & $\begin{array}{c}\text { Epiplatform } \\
\text { orogenic }\end{array}$ & $\begin{array}{c}\text { Turan } \\
\text { platform }\end{array}$ \\
\hline Semi-desert & $\begin{array}{l}\text { Delta of Amu Darya River, along irrigation } \\
\text { canals, along river channels lenses of fresh water } \\
\text { reserves }\end{array}$ & - & $>1$ \\
\hline Mountain & Hydrogeological massifs & $0.95-2.6$ & 2.1 \\
\hline $\begin{array}{l}\text { Valley- } \\
\text { piedmont }\end{array}$ & $\begin{array}{l}\text { Inter-mountain depressions, river floodplains, } \\
\text { piedmont loops, discharge cones }\end{array}$ & $18-50$ & $20-40$ \\
\hline Strata & Artesian reservoirs & $95-640$ & $170-1480$ \\
\hline Desert & Lenses of fresh groundwater resources of deserts & - & $<650$ \\
\hline
\end{tabular}


Table 2. Forecasted groundwater reserves with a mineralization of less than $5 \mathrm{~g} / \mathrm{l}$ in Uzbekistan (Mirzaev 1974; Borisov 1990)

\begin{tabular}{cccll}
\hline Mineralization & $\begin{array}{c}\text { GW } \\
\text { Reserves } \\
\left(\mathbf{k m}^{3} / \mathbf{y} \text { ear }\right)\end{array}$ & $\begin{array}{c}\% \\
\text { to } \\
\text { total }\end{array}$ & GW category & \multicolumn{1}{c}{ Description for use } \\
\hline$<1 \mathrm{~g} / 1$ & 7.32 & 37 & Fresh & $\begin{array}{l}\text { All purposes } \\
\text { Rural potable supply, irrigation, } \\
\text { animals }\end{array}$ \\
$1-1.5 \mathrm{~g} / \mathrm{l}$ & 2.61 & 13 & Good quality & Irrigation, rural potable supply \\
& 7.42 & 38 & Slight saline & $\begin{array}{l}\text { Irrigation and watering husbandry } \\
1.5-3.0 \mathrm{~g} / 1\end{array}$ \\
$3-5 \mathrm{~g} / 1$ & 1.26 & 7 & Saline & Moderate and \\
$5 \mathrm{~g} / \mathrm{l}>$ & 0.98 & 5 & $\begin{array}{l}\text { Industry and irrigation of salt- } \\
\text { tolerant crops }\end{array}$ \\
\hline Total & 19.6 & 100 & & \\
\hline
\end{tabular}


Table 3. Number of aquifers in administrative provinces of Uzbekistan as of 2004 (Goskompriroda of Uzbekistan 2005)

\begin{tabular}{lccccc}
\hline \multicolumn{1}{c}{ Province } & $\begin{array}{c}\text { Number of } \\
\text { aquifers }\end{array}$ & \multicolumn{4}{c}{ Groundwater resources $\left(\mathbf{k m}^{\mathbf{3}} / \mathbf{y e a r}\right)$} \\
\cline { 3 - 6 } & & $\begin{array}{c}\text { Total } \\
\text { available }\end{array}$ & $\begin{array}{c}\text { Approved } \\
\text { for use }\end{array}$ & $\begin{array}{c}\text { Total } \\
\text { withdrawal }\end{array}$ & $\begin{array}{c}\text { \% of GW withdrawal } \\
\text { to approved reserves }\end{array}$ \\
\hline Andijan & 6 & 2.28 & 0.69 & 0.47 & 68 \\
Ferghana & 6 & 3.08 & 2.48 & 1.76 & 71 \\
Namangan & 8 & 2.87 & 3.24 & 0.54 & 17 \\
Syrdarya & 4 & 3.08 & 0.24 & 0.39 & 163 \\
Jizzak & 8 & 0.32 & 0.27 & 0.10 & 37 \\
Samarkand & 14 & 0.36 & 0.78 & 0.66 & 85 \\
Tashkent & 8 & 2.97 & 3.24 & 0.99 & 31 \\
Kashkadarya & 5 & 0.63 & 0.32 & 0.69 & 216 \\
Surkhandarya & 6 & 0.61 & 0.18 & 0.37 & 206 \\
Bukhara & 3 & 0.98 & 0.15 & 0.29 & 193 \\
Navoi & 4 & 0.43 & 0.43 & 0.18 & 42 \\
Khorezm & 7 & 2.99 & 0.32 & 0.02 & 6 \\
Karakalpakstan & 9 & 2.49 & 0.24 & 0.03 & 13 \\
\hline Total & $\mathbf{8 8}$ & $\mathbf{2 3 . 0 1}$ & $\mathbf{8 . 5 9}$ & $\mathbf{5 . 7 1}$ & \\
\hline
\end{tabular}


Table 4. Melioration regime characteristics (Reshetkina 1965; Dukhovny et al. 2005; Ikramov 2006)

\begin{tabular}{|c|c|c|c|}
\hline $\begin{array}{l}\text { Melioration } \\
\text { regime }\end{array}$ & $\begin{array}{c}\text { Groundwater engagement in } \\
\text { irrigation }\end{array}$ & $\begin{array}{c}\text { Supply from } \\
\text { groundwater and } \\
\text { melioration share } \\
\left({ }^{\cdot} 000 \mathrm{~m}^{3} / \mathrm{ha}\right)\end{array}$ & $\begin{array}{c}\text { Evaporation of } \\
\text { Groundwater } \\
\left({ }^{\circ} 000 \mathrm{~m}^{3} / \mathrm{ha}\right)\end{array}$ \\
\hline Automorphic & $\begin{array}{l}\mathrm{GW} \text { is not engaged in irrigation, } \\
\text { free downward infiltration }\end{array}$ & $\begin{array}{l}-\mathrm{I}_{\mathrm{t}}<0.05-0.1 \mathrm{x}(\mathrm{ET}-\mathrm{P}) \\
\mathrm{M}=0\end{array}$ & 0 \\
\hline $\begin{array}{l}\text { Semi- } \\
\text { automorphic }\end{array}$ & $\begin{array}{l}\text { GW underlay infiltration of } \\
\text { irrigation water and insignificant } \\
\text { engaged in plant supply }\end{array}$ & $\begin{array}{l}+\mathrm{I}_{\mathrm{t}}<0.1-0.2 \mathrm{x}(\mathrm{ET}-\mathrm{P}) \\
\mathrm{M}=0.5-1.0\end{array}$ & $0-1.5$ \\
\hline $\begin{array}{l}\text { Semi- } \\
\text { hydromorphic }\end{array}$ & $\begin{array}{l}\text { GW actively engaged in plant } \\
\text { water supply surpassing } \\
\text { irrigation water }\end{array}$ & $\begin{array}{l}+\mathrm{I}_{\mathrm{t}}>0.3 \mathrm{x}(\mathrm{ET}-\mathrm{P}) \\
\mathrm{M} \geq 2.0\end{array}$ & $1.5-3.0$ \\
\hline Hydromorphic & Plant supply is mainly from GW & $\begin{array}{l}+\mathrm{I}_{\mathrm{t}}>(\mathrm{ET}-\mathrm{P}) \\
\mathrm{M} \geq 5.0\end{array}$ & $3.0-7.0$ \\
\hline
\end{tabular}


Table 5. Major transboundary aquifers and environmental and management issues in Uzbekistan (UNECE 2009)

\begin{tabular}{|c|c|c|c|c|c|}
\hline Aquifer & Type* & Shared by & $\begin{array}{l}\text { Pressure } \\
\text { factors }\end{array}$ & $\begin{array}{l}\text { Transboundary } \\
\text { Impacts }\end{array}$ & $\begin{array}{l}\text { Environmental } \\
\text { Issues }\end{array}$ \\
\hline Osh Aravoj & Medium & $\begin{array}{l}\text { Uzbekistan } \\
\text { Kyrgyzstan }\end{array}$ & $\begin{array}{l}\text { Agriculture } \\
\text { Industry } \\
\text { Water disposal }\end{array}$ & $\begin{array}{l}\text { Decline of GW table } \\
\text { Pollution }\end{array}$ & $\begin{array}{l}\text { Pesticides } \\
\text { Heavy metals } \\
\text { Hydrocarbons } \\
\text { Radioactive elements }\end{array}$ \\
\hline $\begin{array}{l}\text { Almoe- } \\
\text { Verzin }\end{array}$ & Medium & $\begin{array}{l}\text { Uzbekistan } \\
\text { Kyrgyzstan }\end{array}$ & $\begin{array}{l}\text { Agriculture Ore } \\
\text { mining Water } \\
\text { disposal }\end{array}$ & Pollution & $\begin{array}{l}\text { Nitrogen species } \\
\text { Pesticides } \\
\text { Heavy metals } \\
\text { Hydrocarbons }\end{array}$ \\
\hline Moiabsuv & $\begin{array}{l}\text { Strong to } \\
\text { medium }\end{array}$ & $\begin{array}{l}\text { Uzbekistan } \\
\text { Kyrgyzstan }\end{array}$ & $\begin{array}{l}\text { Agriculture } \\
\text { Industry }\end{array}$ & Pollution & $\begin{array}{l}\text { Hydrocarbons } \\
\text { Sulphates }\end{array}$ \\
\hline Sokh & Strong & $\begin{array}{l}\text { Uzbekistan } \\
\text { Kyrgyzstan }\end{array}$ & $\begin{array}{l}\text { Agriculture } \\
\text { Industry }\end{array}$ & Pollution & Salinization \\
\hline Pretashkent & $\begin{array}{l}\text { Large deep } \\
\text { (artesian } \\
\text { type) }\end{array}$ & $\begin{array}{l}\text { Uzbekistan } \\
\text { Kazakhstan }\end{array}$ & $\begin{array}{l}\text { Water } \\
\text { abstraction }\end{array}$ & Decline of GW table & $\begin{array}{l}\text { No significant } \\
\text { problems }\end{array}$ \\
\hline $\begin{array}{l}\text { Birata- } \\
\text { Urgench }\end{array}$ & $\begin{array}{l}\text { Quaternary } \\
\text { sand, loam }\end{array}$ & $\begin{array}{l}\text { Uzbekistan } \\
\text { Turkmenistan }\end{array}$ & $\begin{array}{l}\text { Water } \\
\text { abstraction }\end{array}$ & $\begin{array}{l}\text { Moderate borehole yield } \\
\text { reduction }\end{array}$ & $\begin{array}{l}\text { Salinization (natural } \\
\text { origin and irrigation) } \\
\text { Wastewater and } \\
\text { drainage water } \\
\end{array}$ \\
\hline Karotog & Moderate & $\begin{array}{l}\text { Uzbekistan } \\
\text { Tajikistan }\end{array}$ & $\begin{array}{l}\text { Water } \\
\text { abstraction }\end{array}$ & $\begin{array}{l}\text { Change of water } \\
\text { resources based on the } \\
\text { water abstraction in } \\
\text { Tajikistan }\end{array}$ & Nitrate contamination \\
\hline Dalverzin & Moderate & $\begin{array}{l}\text { Uzbekistan } \\
\text { Tajikistan }\end{array}$ & $\begin{array}{l}\text { Water } \\
\text { abstraction }\end{array}$ & $\begin{array}{l}\text { Moderate borehole yield } \\
\text { reduction }\end{array}$ & $\begin{array}{l}\text { Moderate increase on } \\
\text { mineralization and } \\
\text { hardness }\end{array}$ \\
\hline Zaforoboi & Moderate & $\begin{array}{l}\text { Uzbekistan } \\
\text { Tajikistan }\end{array}$ & $\begin{array}{l}\text { Water } \\
\text { abstraction }\end{array}$ & $\begin{array}{l}\text { Moderate borehole yield } \\
\text { reduction }\end{array}$ & Moderate pollution \\
\hline Zeravshan & Moderate & $\begin{array}{l}\text { Uzbekistan } \\
\text { Tajikistan }\end{array}$ & $\begin{array}{l}\text { Moderate water } \\
\text { abstraction }\end{array}$ & $\begin{array}{l}\text { Significant effect of the } \\
\text { industrial activities in } \\
\text { Tajikistan }\end{array}$ & Industry \\
\hline $\begin{array}{l}\text { Chatkal- } \\
\text { Kurman }\end{array}$ & Weak & $\begin{array}{l}\text { Kazakhstan } \\
\text { Uzbekistan }\end{array}$ & $\begin{array}{l}\text { Water } \\
\text { abstraction }\end{array}$ & Decline of GW table & $\begin{array}{l}\text { No significant } \\
\text { problems }\end{array}$ \\
\hline
\end{tabular}

* Hydraulic link with surface runoff 


\section{FIGURES}

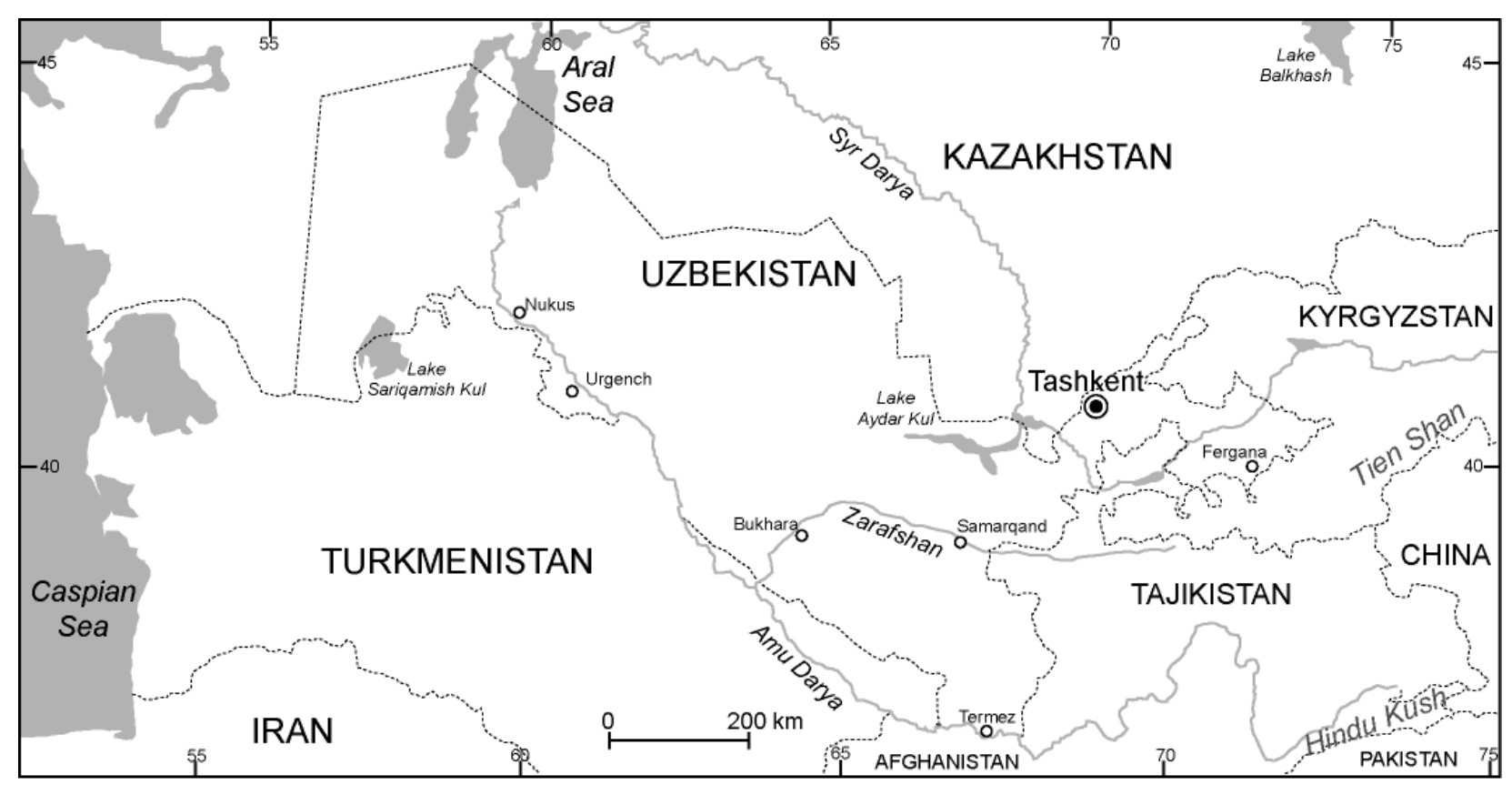

Figure 1 


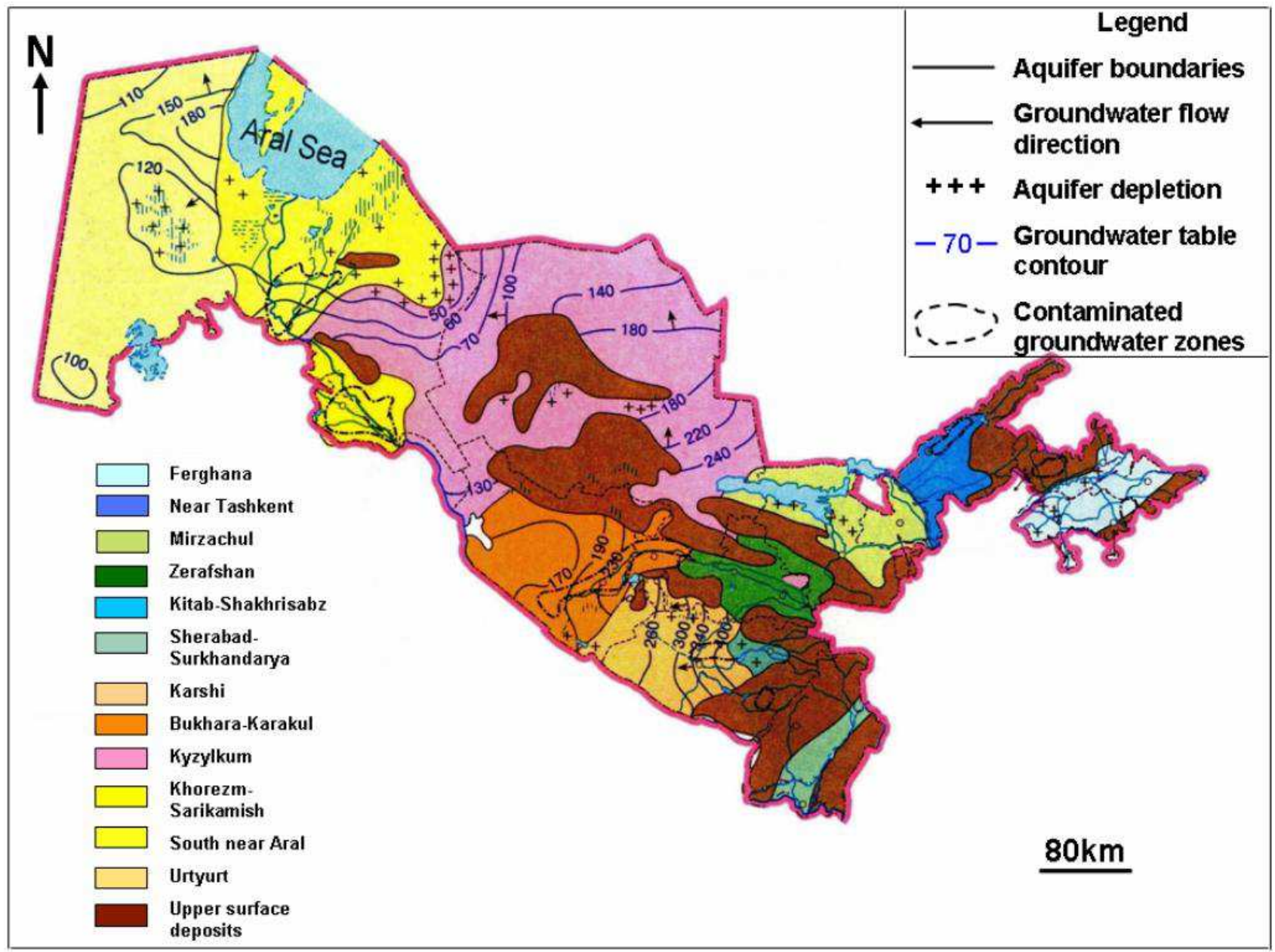

Figure 2 


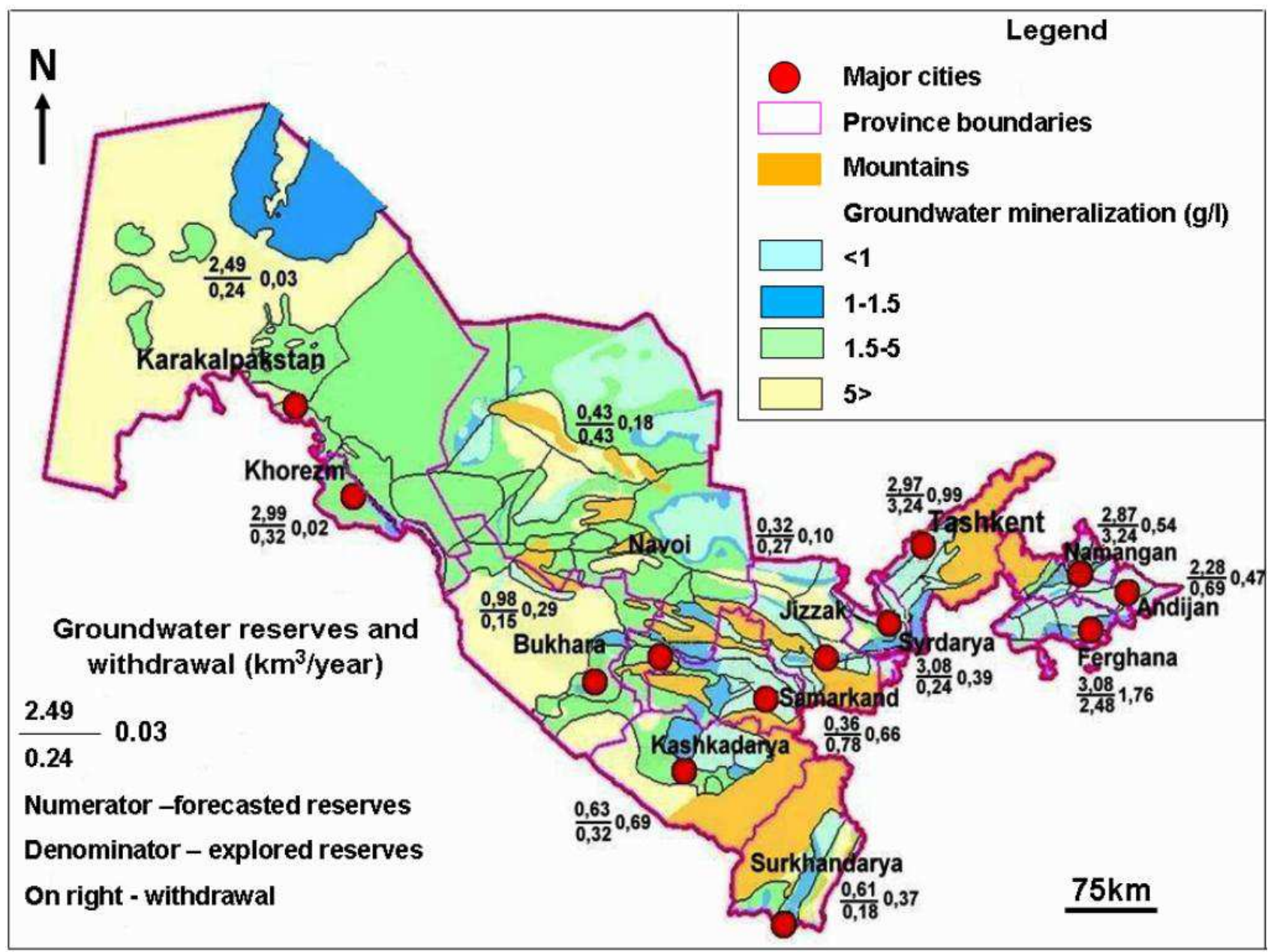

Figure 3 


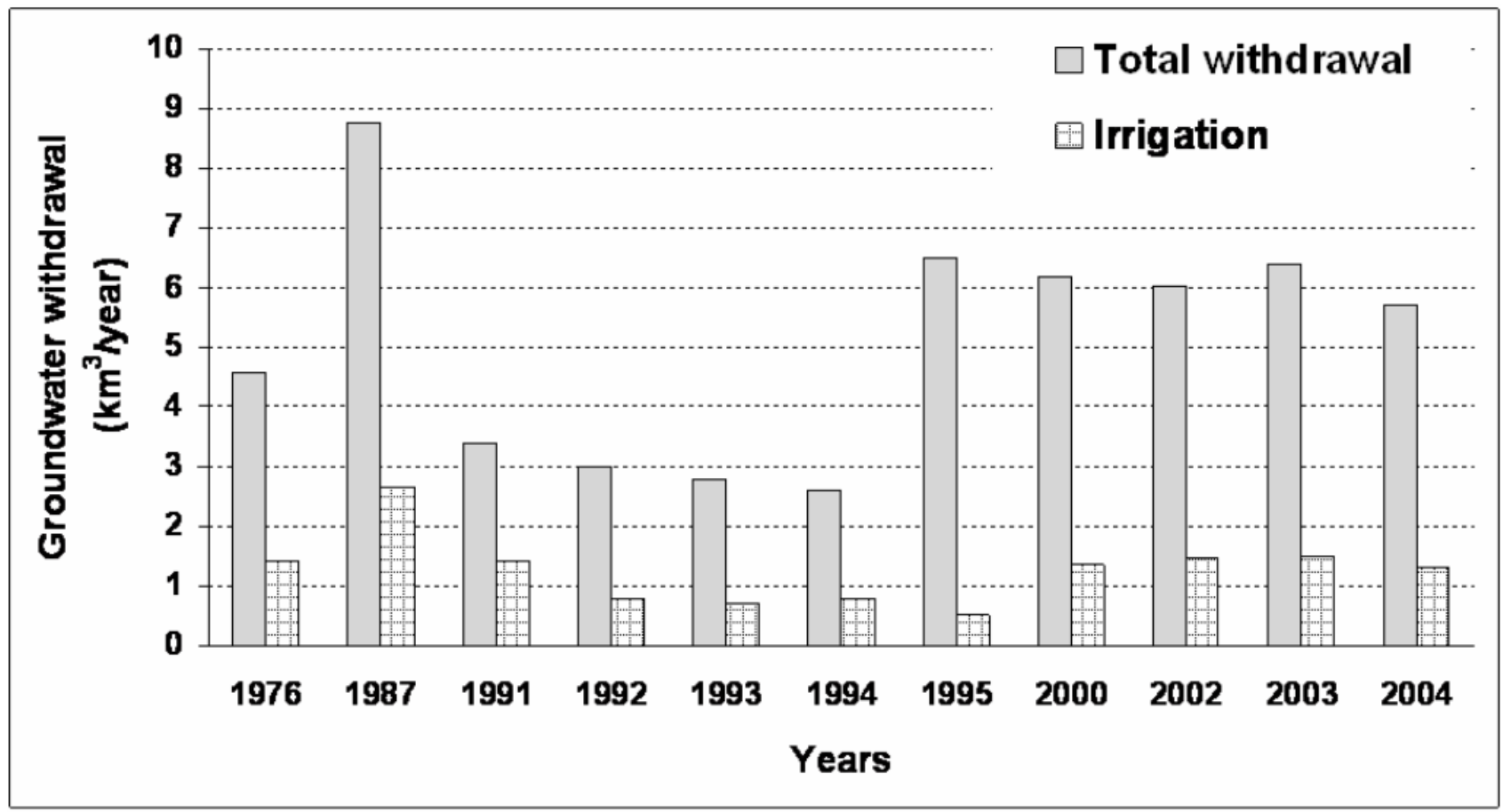

Figure 4 


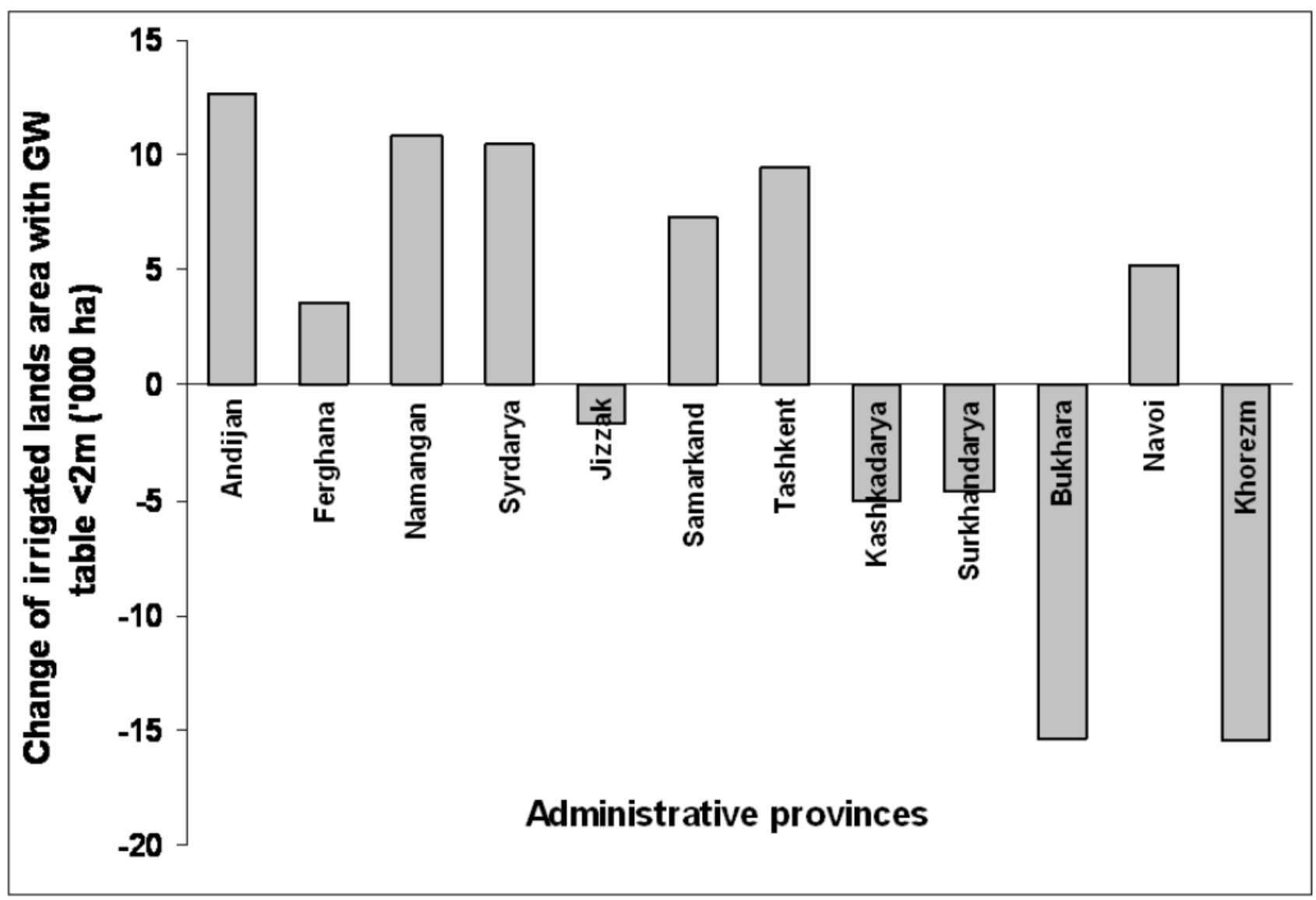

Figure 5 


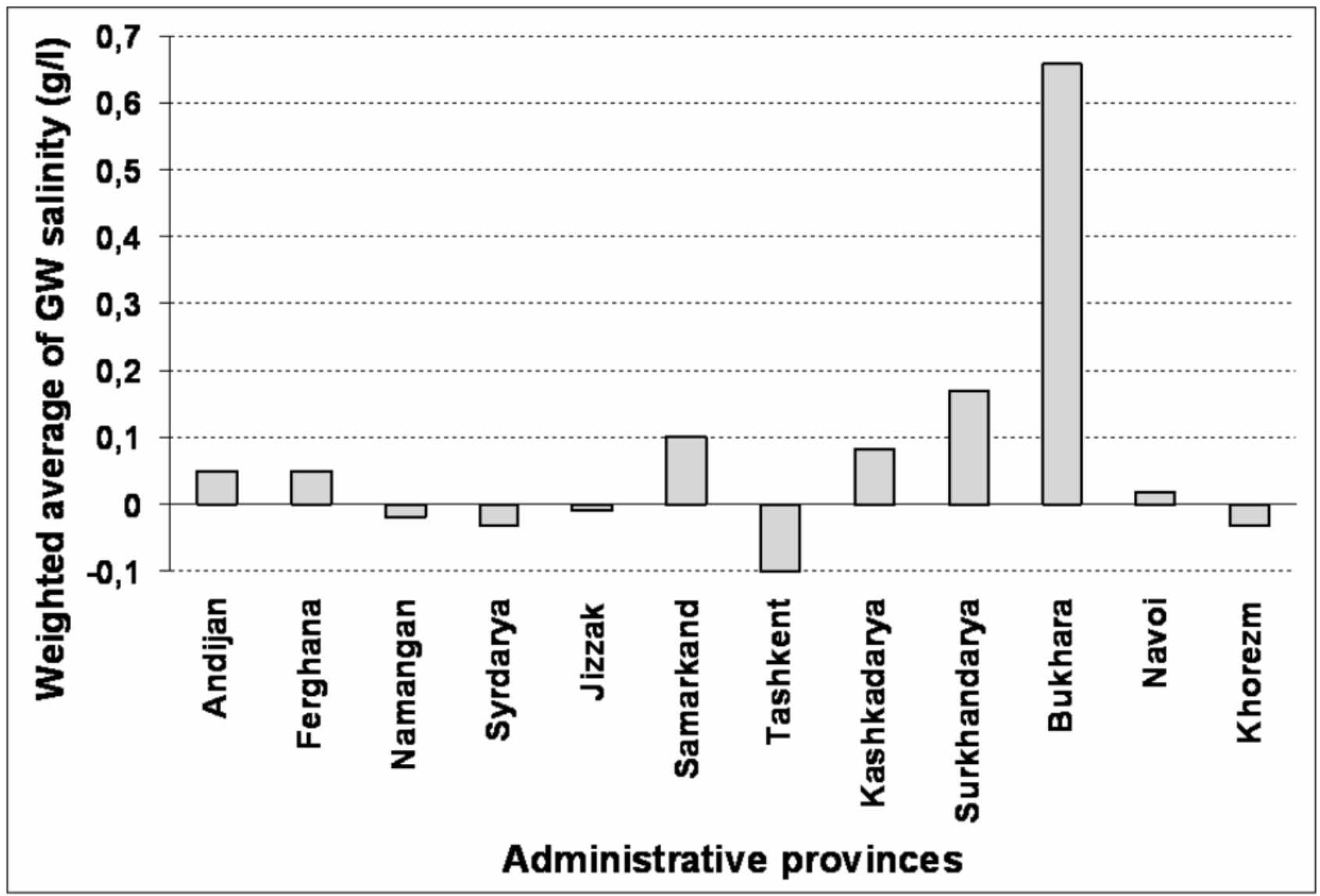

Figure 6 


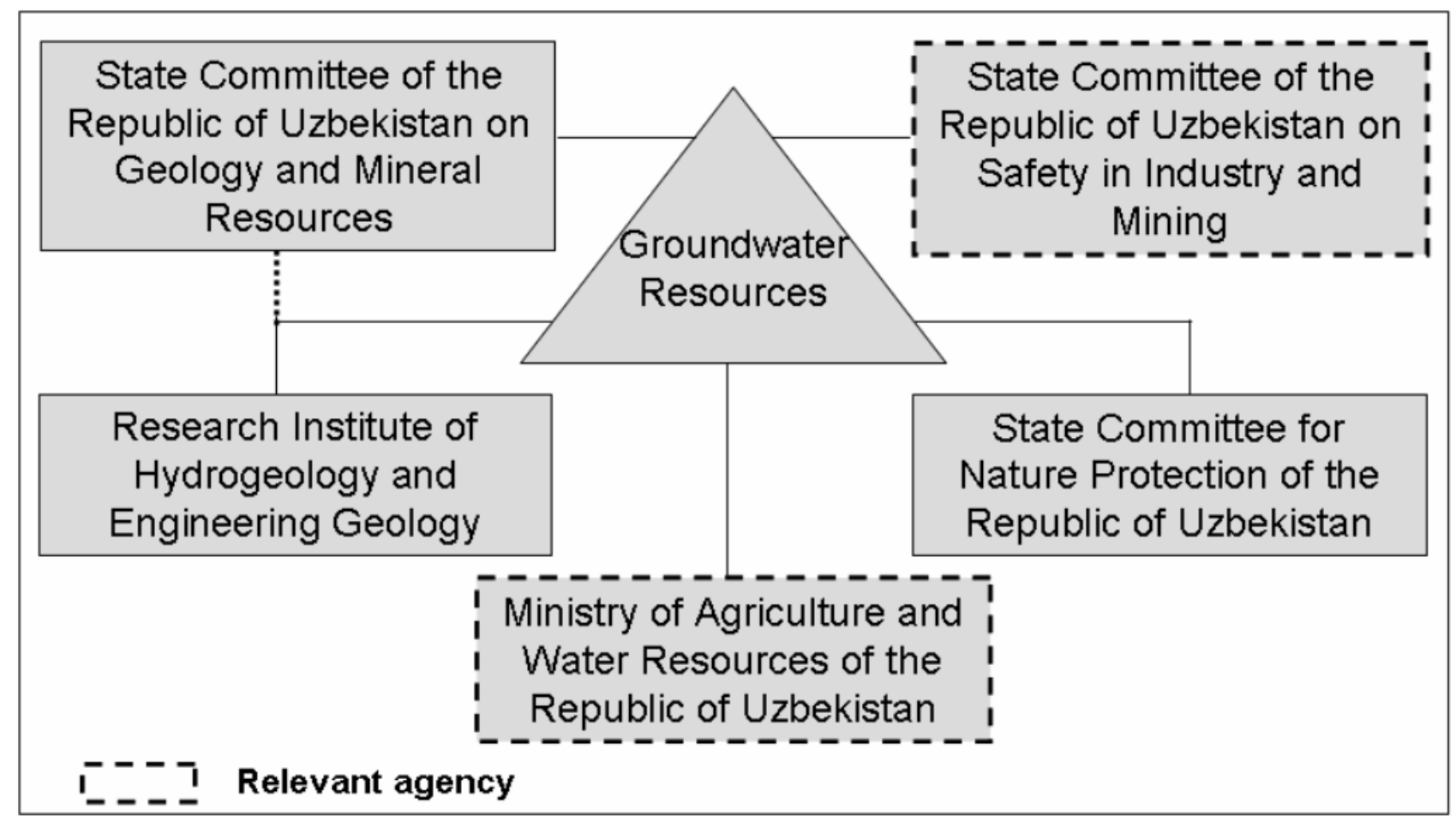

Figure 7 